DOI: $10.24193 /$ tras.65E.2

Published First Online: 02/25/2022

\section{CLIMATE CHANGE (POLICY) \\ SKEPTICISM: POLICY PERFORMANCE \\ RISK AND SUPPORT FOR FOSSIL FUEL \\ TAXATION AMONG EUROPEANS}

\author{
Jesse W. CAMPBELL
}

Jesse W. CAMPBELL

Associate professor, Department of Public Administration, Incheon National University, Incheon, South Korea

E-mail: jcampbell@inu.ac.kr

\section{Abstract}

Concern about climate change does not translate unconditionally into support for policy action, and some citizens are skeptical that (costly) public policies will address climate change effectively. I argue that risks to policy performance at the country level attenuate the link between climate change concern and support for policy action. Using a large sample of public opinion data from residents in 23 (mostly) European countries and both country and respondent-level estimates of policy performance risk, I demonstrate that the link between climate change concern and support for fossil fuel taxation is weaker for citizens in countries where policy performance is threatened. This result holds regardless of whether risk is operationalized as governance or economic risk. I discuss the need to overcome climate change policy skepticism in contexts with stronger policy performance risk profiles.

Keywords: climate change, climate policy, fossil fuel tax, policy implementation, policy risk. 


\section{Introduction}

Due to the magnitude of the problem, policy that is sufficiently ambitious to slow the rate of climate change and reduce its harmful effects entails sacrifices for all citizens. Citizens that are more concerned about climate change are more willing to bear these costs (Fairbrother, Sevá and Kulin, 2019). However, concern about climate change does not translate unconditionally into support for policy action (Fairbrother, 2016). If citizens are skeptical that their sacrifices will produce climate-relevant outputs, their support for climate change policy may be tempered (Davidovic, Harring and Jagers, 2020; Tam and Chan, 2017), and even those with the strongest environmental values may reject policy initiatives they would otherwise favor. Policy performance risk, or the probability that a given policy initiative will underperform or fail, is therefore a potentially important predictor of support for climate change policy and may help explain why environmental concern does not universally entail higher levels of policy support. Understanding the factors that underlie climate change policy support is a pressing goal, as, particularly in democratic countries, political actors will be reluctant to champion unpopular policies, resulting in an insufficient policy response and potentially a climate disaster (Davidovic and Harring, 2020; Hao, Liu and Michaels, 2020).

Levying a tax on fossil fuel consumption has been identified as an effective and efficient way to address the climate change challenge (Aldy and Stavins, 2012; Fairbrother, 2016). However, the adoption of a fossil fuel taxation regime that is sufficiently ambitious and robust to address the issue faces resistance from many citizens (Davidovic and Harring, 2020). In this study, I survey the policy failure literature and propose a model of support for fossil fuel taxation based jointly on climate change concerns and contextual factors that determine levels of governance and economic policy performance risk. Factors at both the formulation and implementation stages of the policy cycle can determine policy performance (Bovens and 't Hart, 2016; Howlett, 2012; Peters, 2015), and I develop a governance policy risk index built from national-level estimates of regulatory red tape, patronage recruitment, and (a lack of) government transparency. These factors capture public administration-specific phenomena, which have not received extensive treatment in the environmental psychology literature. Second, fossil fuel dependency will drive up the cost of a fossil fuel taxation regime, increase its complexity, and multiply the chances of adverse and unexpected policy outcomes (Hao, Liu and Michaels, 2020; Harring, Jagers and Matti, 2019; Pohjolainen et al., 2021). Unlike governance risk, these factors are specific to the implementation and output of a fossil fuel tax and may, in turn, shape citizen support for the program. I measure economic policy performance risk by combining production and consumption levels of fossil fuels at the national level. Using a multi-level regression approach (Hox, Moerbeek and van de Schoot, 2017), I link these country-level factors to citizen support for fossil fuel taxation, with higher levels of risk associated with lower levels of support. Second, I show how both 'flavors' of policy performance risk attenuate the link between climate change concern and support for fossil fuel taxation, demonstrating that in high-risk contexts, the policy preferences of those strongly concerned with climate change converge with those who are less burdened by concern. 
In the next section, I discuss climate change concern and its relationship with support for climate policy, and then move on to factors that are likely to undermine policy performance, linking these to policy support. After describing the theoretical model and stating my hypotheses, I conduct empirical tests. Using a large sample of residents across 23 (mostly) European countries, I provide evidence that the link between climate concern and support for fossil fuel taxation weakens as policy performance risk increases. In the final section, I discuss the limitations of this study and the questions it leaves for future research. This study adds value by identifying contextual factors relevant to the performance of climate policy and linking them with citizen support for a flagship climate change mitigation policy.

\section{Literature overview}

\subsection{Climate change concern and support for fossil fuel taxation}

The issue of environmental concern has attracted interest from different academic perspectives including sociology, psychology, and political science (Cruz, 2017). Environmental concern captures the extent to which individuals are worried about the personal, societal, and environmental impact of environmental problems (Schultz, 2001), and the construct has both a cognitive and an affective component (Sundblad, Biel and Gärling, 2007). Research has focused on both contextual and individual drivers of environmental concern, including levels of environmental degradation and $\mathrm{CO}_{2}$ emissions (Echavarren, 2017; Hao, 2016; Luís, Vauclair and Lima, 2018; Tranter and Booth, 2015), economic development (Mayerl and Best, 2018; Nawrotzki, 2012), religiosity (Felix et al., 2018), postmaterialism and human values (Mayerl and Best, 2018; Poortinga et al., 2019), and socio-economic status, political orientation, and other demographic factors (Chan, Pong and Tam, 2019; Pampel, 2014; Van Heuvelen and Summers, 2019). In this study, I focus exclusively on climate change concern, which has received attention in some recent studies (Davidovic and Harring, 2020; Fairbrother, Sevä and Kulin, 2019).

While some work on environmental concern equates it with a willingness to behave in a pro-environmental fashion (Dunlap and Jones, 2002), concern and support are distinct concepts and some factors (such as perceived policy fairness or effectiveness) that predict various forms of environmental policy support (Dreyer and Walker, 2013; Schade and Schlag, 2003) are less likely predictors of concern. Concern and policy support (or other relevant behaviors), therefore, are related, but they are not conceptually equivalent, and nor is one a linear function of the other. Much like political support (Easton, 1975), support for increased fossil fuel taxation is a policy-specific attitude that runs from unfavorable to favorable. Although concern with climate change is now widespread globally, concern may not automatically translate into support for ambitious environmental policy (Bamberg and Möser, 2007; Hornsey et al., 2016). This 'concern-behavior gap' (Kollmuss and Agyeman, 2002; Tam and Chan, 2017) can be a function of individual-level differences such as trust (Fairbrother, Sevá and Kulin, 2019; Tam and Chan, 2018) or contextual factors such as the general quality of the legislative, executive, and judicial branches of 
government (Davidovic, Harring and Jagers, 2020) or the institutionalization of strategies to address collective action problems (Doyle, 2018). I argue that policy performance risk widens the concern-behavior gap.

\subsection{Policy performance risk and fossil fuel taxation}

Policy performance risk captures the probability that a given policy will fail to produce the outcomes that are the policy's specified objectives. Policies seldom fail or succeed entirely (Baldwin, 2000; McConnell, 2010), and Peters (2015, p. 261) writes that the 'causes identified for failure in the policy literature are legion'. In the public sector, predicting future performance, and even linking past behavior to specific outputs is challenging (Campbell, 2021), and conceptualizing the factors leading to policy performance should not be reduced to a single causal perspective or be limited to an isolated phase of the policy cycle (Bovens and 't Hart, 2016; Howlett, 2012). For any complex policy, numerous elements at the design, initial implementation, and ongoing maintenance phases of the policy cycle can all play a role in shaping performance or failure (Peters, 2015). Moreover, performance in the public sector is complex and knowledge of value trade-offs (for instance, equity vs. efficiency) can shape perceptions about the desirability and legitimacy of policy initiatives (Campbell, 2020a), making consensus about relevant performance criteria elusive. Climate policy specifically is multi-dimensional and complex, and both (partial) policy success and failure may occur in a single context (Newman and Head, 2015). Governments have different instruments available to them to reduce undesirable energy usage including taxes, subsidies, bans, and usage regulations, and Davidovic and Harring (2020) note that these choices vary in both their design and coerciveness. However, Fairbrother (2016) argues that environmental taxes are looked on favorably among these choices as they address the market failures driving environmental damage efficiently by 'attaching a price to activities proportionate to the harms they cause' (p. 361).

Although theoretically compelling, a range of factors rooted in the context of implementation can threaten the performance of a fossil fuel usage taxation regime. Such threats have distributive consequences, as underperformance will not affect all stakeholders equally; some will bear disproportionate costs, while others will benefit at their expense (Davidovic, Harring and Jagers, 2020; Fairbrother et al., 2021; Rafaty, 2018). Given that the value of the sacrifices made by stakeholders is dependent on like sacrifices being made by others, failure to distribute these equitably renders any sacrifice less meaningful. Policy performance risk, therefore, translates into individual risk. Svallfors (2013) argues that a perception among citizens that the state can deliver on its promises increases tolerance of taxation for ambitious social spending programs, and provides evidence for this proposition using data from 29 (mostly) European countries. Conversely, however, even if stakeholders value the intended goal of a policy (whether it be alleviating poverty or combatting climate change), skepticism about the ability of the state to design, initiate, and carry out the policy in an effective manner will erode the willingness to undertake the sacrifices necessary to realize it. 
Based on the logic presented above, the generalized form of the hypotheses of this study can be stated as follows:

Hypothesis 1: Climate change concern is positively associated with support for fossil fuel taxation.

Hypothesis 2: Policy performance risk is negatively associated with support for fossil fuel taxation.

Hypothesis 3: Policy performance risk negatively moderates the relationship between climate change concern and support for fossil fuel taxation.

Below, I elaborate on each of these hypotheses by discussing different elements of policy performance risk. I first discuss governance risks that are based on the characteristics of national bureaucracies, and then discuss economic risks that are specific to the successful implementation of a fossil fuel taxation regime.

\subsubsection{Governance policy performance risk}

Governance policy performance risk is a function of deficiencies in the state administrative system that undermine its ability to create and maintain an effective policy program. Following Peters (2015) and others, I conceive of these at the formulation, implementation, and monitoring phases of the policy cycle.

At the policy formulation stage, high levels of regulatory red tape increase policy performance risk. While a fossil fuel consumption taxation regime will entail some level of sacrifice for virtually all members of society, it is the business sector rather than individual citizens that is the primary consumer of fossil fuels. Although the opportunism and avarice of business has been criticized for its role in creating the climate crisis, the private sector is nevertheless the main driver of economic growth, the primary provider of employment, as well as a significant contributor to the public budget. While the goal of a fossil fuel taxation regime is to reduce the consumption of fossil fuels, there are more and less efficient ways to achieve this. Red tape refers to rules and procedures that entail a compliance burden for those subject to them but contribute little to the goals for which they were created (Bozeman, 1993; Campbell, 2019; Pandey, 2021). Higher levels of red tape are linked to suboptimal levels of performance for public organizations (George et al., 2021), and citizens tend to see public policy as red tape when it fails to achieve its stated goals (Ahn and Campbell, 2022). All organizations are exposed to government regulation to some degree, and red tape is also relevant to private companies, whose performance can suffer as a result of ill-conceived and burdensome laws (Kaufmann, Hooghiemstra and Feeney, 2018; de Jong and van Witteloostuijn, 2015). While all laws and regulations impose some level of compliance burden upon businesses, when this burden unduly undermines performance without contributing to policy objectives, it devolves into red tape. The level of red tape typical of a given regulatory regime should weaken the link between climate change concern and support for fossil fuel taxation as it increases compliance costs for private sector actors and thereby the costs of the program relative to its benefits. Additionally, high levels 
of regulatory red tape entail more intensive interaction between government officials and private sector actors, which is not only a source of waste but also presents opportunities for corruption.

The policy performance of a fossil fuel taxation regime will not be determined solely by its design but also by the effectiveness with which it is implemented. Downstream policy failure becomes more likely to the extent that organizations and individuals within the public bureaucracy fail to coordinate their efforts and focus instead on narrow goals (Peters, 2015). Consequently, bureaucratic quality will impact policy performance. Bureaucratic quality can be understood variously, however, how public employees are hired into the public bureaucracy has been repeatedly shown to be a critical factor in the performance of public institutions (Dahlström, Lapuente and Teorell, 2012; Evans and Rauch, 1999), perhaps functioning as a prerequisite for high levels of performance (Campbell, 2020b). A public hiring process that focuses on the skills and qualifications of the potential employee will, in general, produce a higher capacity public workforce better able to resist the corrupting temptations associated with public authority (Sundell, 2014). In contrast, when the hiring process is centered upon the personal or political connections of applicants, not only will the quality of the average employee decline, but the highly personalized hiring process may persist throughout employment, undermining the independence and neutrality of the public workforce and facilitating collusion (Campbell, 2020b). Implementation is critical to the performance of public policy, as it is in the implementation stage that policy can fail to meet specified criteria and ultimately damage rather than benefit a target group (McConnel, 2010; Olavarría-Gambi, 2020). Due to the detrimental effect of patronage-based recruitment on public service performance, citizens that are concerned about climate change should be more reluctant to support ambitious climate change reduction policy when patronage has undermined the capacity and integrity of the public bureaucracy. Moreover, the complexity of a fossil fuel taxation regime will present many opportunities for corruption and, to the extent that a patronage-based bureaucracy has fewer internal checks against corrupt behavior, a taxation regime may ultimately have less efficacy when implemented if patronage recruitment prevails.

Finally, while patronage recruitment may undermine the internal accountability of climate policy action, external actors can also play a critical role in holding public servants accountable for their actions. Access to information is a key mechanism by which citizens can hold the government to account and bring incompetent or corrupt behavior to the attention of the public (Chowdhury, 2004), and a free press also augments the effectiveness of other anti-corruption controls including democratic elections (Kalenborn and Lessmann, 2013) and civil society strength (Themudo, 2013). However, journalists and private media organizations, both domestic and foreign, can play their role as agents of accountability to the extent that they are permitted access to relevant policymakers, government documents, and data. Opening up the operations of government to the public, journalists, and civil society, as well as other government agencies, provides incentives for civil servants to maintain patterns of policy implementation consistent with the rule of law. In other words, without the expectation that government records will be open to scrutiny, both internally 
and to external stakeholders, the ability of the government to make a credible commitment to the implementation of a fossil fuel taxation regime is impaired. Moreover, as a marketbased approach, the viability of a fossil fuel taxation scheme relies on the free flow of information, which allows businesses to make accurate resource forecasts and engage in strategic planning. Secrecy entails risks to policy performance, and citizens may be hesitant to support complex and ambitious policy initiatives when there are ample opportunities for misconduct or incompetence, or when sufficient clarity necessary for the realization of policy effectiveness is absent.

Regulatory red tape, patronage recruitment, and a lack of transparency will undermine policy performance independently. Together they represent a risk to the entirety of the policy design, initiation, and implementation pipeline. I group them as components of governance policy performance risk, and hypothesize the following:

Hypothesis 2A: Governance policy performance risk is negatively related to support for fossil fuel taxation.

Hypothesis 3A: Governance policy performance risk negatively moderates the relationship between climate change concern and support for fossil fuel taxation.

\subsubsection{Economic policy performance risk}

Governance policy performance risk is relevant to the performance of government in general. However, not all policies are equally exposed to risk, and the policy-relevant details of a given context can also affect potential performance. Policy-specific beliefs contribute to the acceptability of climate change policy, including fossil fuel taxation (Eriksson, Garvill and Nordlund, 2008). The risks that have been the primary focus of the climate change policy literature focus on the socio-economic risks of climate change itself rather than the risk of policy failure, and the risks associated with the adoption of climate change policy include economic risks (Tompkins and Adger, 2005). The cost to value ratio of any policy is a component of its performance, and, as Newman and Head (2015, p. 345) write, 'excessive cost' is a form of 'negative distributional outcome', as 'the implication is that the opportunity-cost is serious' (McConnell, 2016). Citizens of countries that are more exposed to the cost of fossil fuel taxation may be more reluctant to support expensive taxation policy. This is the case for two reasons. The first is that the negative economic costs of fossil fuel taxation will be felt more in countries in which a greater share of energy production and consumption is fossil-fuel based. In other words, the stakes for the performance of a fossil fuel taxation regime are higher for countries that are larger producers and consumers of fossil fuels. Such risks are reduced to the extent that current benefits from fossil fuel usage are themselves small. Additionally, extensive fossil fuel production and utilization will not only make the costs of a fossil fuel taxation program larger, but it will also increase the size and complexity of the program itself, thereby opening up additional opportunities for mistakes and, potentially, corruption. In short, a fossil fuel taxation regime faces significantly higher costs in high utilization contexts. These costs, in turn, increase the risk of poor policy performance. 
Hypothesis 2B: Economic policy performance risk is negatively related to support for fossil fuel taxation.

Hypothesis 3B: Economic policy performance risk negatively moderates the relationship between climate change concern and support for fossil fuel taxation.

\section{Data and methods}

\subsection{Measuring support for fossil fuel taxation}

The dependent variable for this study comes from Round 8 of the European Social Survey (ESS8, 2016), which includes questions exploring attitudes about climate change and other environmental issues. The dataset consists of individual responses from a representative sample of citizens from 20 European Union countries as well as Switzerland, Russia, and Israel.

On the one hand, the ESS is a limiting factor for this analysis as European countries are highly developed and, therefore, the sample does not represent the full range of possibilities for all variables. On the other hand, precisely because of the high average level of development of European countries, the sample focuses on citizens of those countries that could potentially have a substantive impact on climate change through the introduction of fossil fuel taxation. Moreover, there is significant inter-country variability between European countries for key factors, including the dependent, independent, and moderating variables. European countries also have high quality data available for a range of important country-level factors, allowing for the control of confounding factors that a more diverse sample may preclude. I discuss further issues relating to the dataset in the discussion section below.

The ESS asks respondents to what extent they are in favor of or against 'Increasing taxes on fossil fuels, such as oil, gas and coal' as a means specifically to reduce climate change. This question, which I use to measure support for fossil fuel taxation, is answered on a 5-point scale ranging from 'Strongly in favor' to 'Strongly against'. I reverse the scale such that higher values correspond to higher levels of support. The question has been used by others as a measure of support for fossil fuel taxation (Fairbrother, Sevä and Kulin, 2019; Umit and Schaffer, 2020).

\subsection{Measuring climate concern}

Scholars have variously measured opinions about the environment and climate change. Davidovic, Harring and Jagers (2020), using survey data from the International Social Survey Programme (ISSP), use responses to the question 'Generally speaking, how concerned are you about environmental issues?' to measure 'pro-environmental value orientation'. Others have used answers to the question 'the environment is important to this person; to care for nature and save life resources' from the World Values Survey (WVS) to measure environmental concern (for instance, Tam and Chan, 2018). Fairbrother, Sevä and Kulin (2019), also using the ESS, measure 'beliefs about climate change' using 
three quite diverse questions which ask about the extent of climate change, whether it is being driven by natural or human causes, as well as whether the impact of climate change is expected to be 'good or bad'.

Climate risk judgments have both a cognitive and an affective component (Sundblad, Biel and Gärling, 2007). I measure climate change concern using two questions from the ESS. The first taps the cognitive dimension of concern, asking respondents 'How much have you thought about climate change before today?'. The question is answered on a 5-point scale ranging from 'Not at all' to 'A great deal'. To capture the affective dimension of concern, I use answers to the question 'How worried are you about climate change?'. Respondents again answered on a 5-point scale ranging from 'Not at all worried' to 'Extremely worried'. The two-item index has an alpha value of .69.

This measure has some advantages. Unlike the ISSP and WVS questions, those used here are linked clearly and specifically to concern with climate change, and secondly provide a slightly more nuanced index, capturing both the affective and cognitive dimensions of concern. I note that the third question used by Fairbrother, Sevä and Kulin (2019) (measuring the belief that climate change is driven by human behavior) is a logical condition of effective climate policy rather than a component of concern, and I therefore included it as a control.

\subsection{Measuring governance policy performance risk: regulatory red tape, patronage recruitment, and press freedom}

To measure regulatory red tape, I use data from the Executive Opinion Survey from the World Economic Forum (WEF) (2017). Respondents to the survey include business executives from firms with a range of characteristics. The data attempts to measure factors that are theoretically linked to productivity and measures of administrative burden are available for all countries in the sample. I follow Kaufmann, Hooghiemstra and Feeney (2018) and use the question 'How burdensome is it for businesses in your country to comply with governmental administrative requirements (e.g., permits, regulations, reporting)?'. Answers were recorded on a 7-point scale ranging from 'Extremely burdensome' to 'Not burdensome at all'. I reverse the scale and rescale it from 0 to 1 . The measurement is significantly negatively correlated with both the World Bank's estimate of regulatory quality (World Bank, 2016) as well as an aggregate of indicators from its Doing Business data (Mungiu-Pippidi et al., 2017). For the sake of convenience, I used the Quality of Government Institute Standard Dataset for 2018 and 2019 (Teorell et al., 2018) to source regulatory red tape and other national-level control variables.

To measure the level of patronage-based recruitment in the public bureaucracy, I use two questions from the Quality of Government Expert Survey II (Dahlström et al., 2015a; 2015b). The Expert Survey II consists of country-level estimates of government characteristics across 158 countries (as well as Hong Kong) based on expert assessments, and the data was collected over one year beginning in April of 2014. Questions that were answered by less than three respondents were set to missing in the dataset. The data have been probed 
for validity, with more information available in Dahlström et al. (2015a). I took the average of two questions to measure patronage-based recruitment: 'When recruiting public sector employees, the political connections of the applicants decide who gets the job' and 'When recruiting public sector employees, the personal connections of the applicants (for example kinship or friendship) decide who gets the job'. The two questions capture the extent to which non-merit-based considerations are used in the public sector hiring process and have been used elsewhere to measure the intended construct (Campbell, 2020b). The questions were answered on a 7-point point scale ranging from 'Hardly ever' to 'Almost always'. As with the other two moderators, I rescaled the patronage variable so that all answers fall on a scale of 0 to 1 .

There are several ways to capture government transparency. For example, the WEF's Executive Opinion Survey asks 'How easy is it for businesses in your country to obtain information about changes in government policies and regulations affecting their activities?'. This question has merit but overlaps with the measure of regulatory red tape conceptually and empirically (the two items are correlated at .96). I use instead a measure from the Expert Survey II to measure transparency: 'Government documents and records are open to public access'. This question has face validity and refers to the general openness of government both for citizens and businesses, and is therefore relevant both to compliance and monitoring. The question was answered on a 7-point scale ranging from 'Not at all' to 'To a very large extent'. Although this question comes from the same survey as the measure of patronage recruitment, the scale markers are different and run in the opposite direction (that is, for patronage, higher scores represent more risk in contrast to less risk for transparency). Transparency and the two-item patronage scale are negatively correlated at -.65 , which suggests a degree of convergence but not enough to threaten discriminant validity. I reversed and rescaled the item.

Regulatory red tape, patronage recruitment, and (a lack of) government transparency represent three distinct factors that heighten the risk of policy failure. However, countries that score highly on one of the three subcomponents tend to score highly on the other two. A Cronbach's alpha value of .78 among the countries in the sample suggest also that the three items are internally consistent. To reflect this, I created an index of governance policy performance risk by taking the country average of the three risk factors.

Figure 1 shows the bivariate country-level correlations between governance risk (mean of country responses), climate concern, and support for fossil fuel taxation. Governance risk and climate change have a (negative) correlation coefficient of below .04 ( $>$ > .05), suggesting that climate concern varies independently of governance risk. In contrast, support for fossil fuel taxation (country mean) is negatively correlated with governance risk at the country level $(\mathrm{r}-0.63, \mathrm{p}<.01)$, a statistic that is consistent with hypothesis $2 \mathrm{~A}$. 

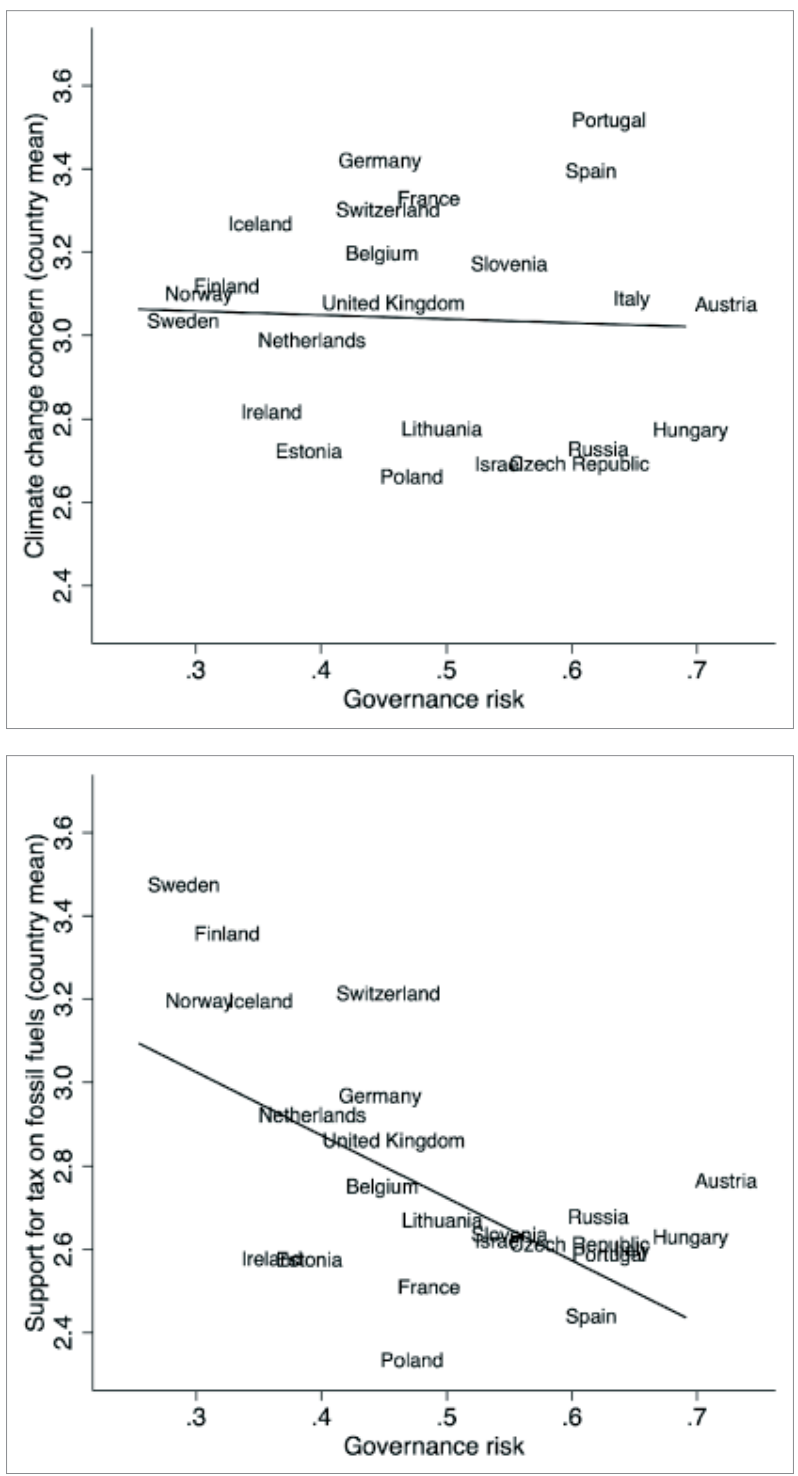

Figure 1: Governance risk, climate concern, and support for fossil fuel taxation

Source: The author

\subsection{Measuring economic policy performance risk: fossil fuel dependency}

I used data on national fossil fuel energy production and consumption from the World Bank to measure economic policy performance risk. First, for each country I summed up energy production from oil, gas, and coal (i.e., the three primary fossil fuel sources) as a percentage of all energy produced, and then took the average of this total with fossil fuel consumption as a percentage of total energy consumption. These estimates come from the World Bank's World Development Indicators (World Bank, 2016). The statistics are 
correlated at $.87(\mathrm{p}<.001)$ and have a Cronbach's alpha of .92. Together, these measures of production and consumption capture the financial exposure of a given country to fossil fuel taxation and thereby its economic policy performance risk. To compare with governance risk, I rescale the index to range from 0 to 1.

Figure 2 shows the country-level bivariate correlations between economic risk and both climate change concern and support for fossil fuel taxation. Climate change concern and economic risk are correlated at -.34 , but the relationship is not statistically significant $(\mathrm{p}>.05)$. In contrast, economic risk is negatively correlated with support for fossil fuel taxation $(-0.55, \mathrm{p}<.01)$. This is consistent with hypothesis $2 \mathrm{~B}$.
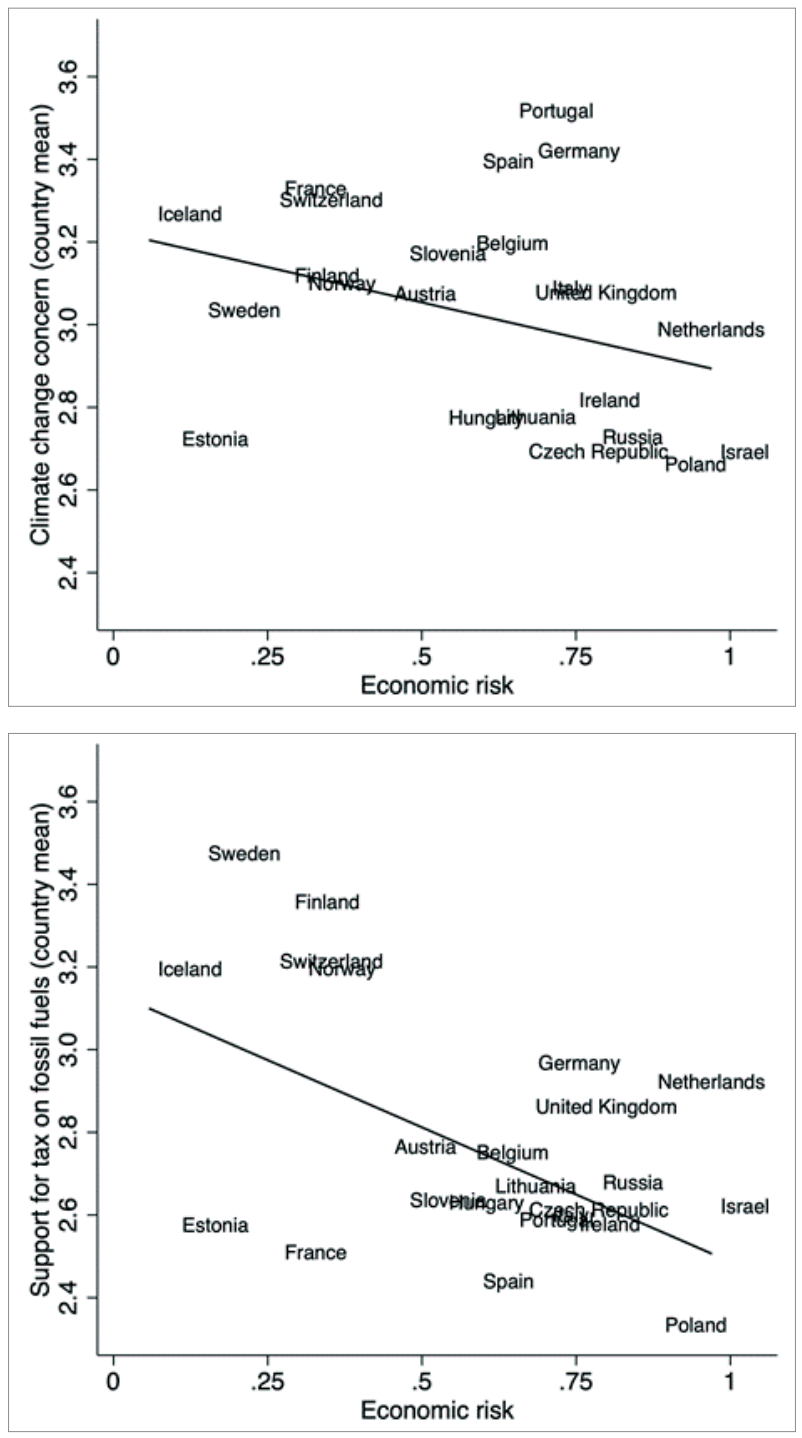

Figure 2: Economic risk, climate concern, and support for fossil fuel taxation

Source: The author 


\subsection{Control variables}

To better isolate the effect of policy performance risk and climate change concern on support for fossil fuel taxation, I controlled for a number of factors at the individual and country level. At the individual level these include demographic and socio-economic factors (gender, age, education, and satisfaction with income) as well as factors that capture relevant beliefs. First, those with a more conservative political orientation tend to be less supportive of climate change policy (Davidovic and Harring, 2020; Davidovic, Harring and Jagers, 2020), and I included a measure of conservative political orientation (answers are on a scale from 0 to 10 spanning a self-estimation of left wing to right wing political views). Second, trust, both generalized and trust in government, has been among the most studied predictors of climate policy support (Fairbrother et al., 2021; Kulin and Johansson Sevä, 2021; Harring, 2013). I measured generalized trust using answers to the prompt 'Most people can be trusted or you can't be too careful', which is answered on a scale from 0 to 10. Trust in government was measured by combining measures of trust in parliament and the legal system. Finally, as addressing climate change can be understood as a collective action problem par excellence (Doyle, 2018; Smith and Mayer, 2018), I controlled for answers to the question of whether other governments will take sufficient action on climate change. Because climate change is a global phenomenon and also entails sacrifices by individual countries, if other countries fail to act, the sacrifices that fossil fuel taxation entails will not have a decisive impact on climate change and make them less meaningful. The question was answered on a 10-point scale ranging from 'Not at all likely' to 'Extremely likely'.

Governance and economic policy performance risk may not be the only country-level factors that affect support for fossil fuel taxation. For governance policy risk, I selected factors that are specifically relevant to the administrative apparatus of the state. To best isolate the effect of governance risk, I first included a control for democratization by using Freedom House's 'level of democracy' imputed polity score (Freedom House, 2019). This control is important, as high levels of democratization entail that the political class is beholden to the citizenry, which will constrain their actions. Second, I included an estimate of judicial independence from the WEF's Executive Opinion Survey. The question asks, 'To what extent is the judiciary in your country independent from influences of members of government, citizens, or firms?' and is answered on a scale from 1 to 7 , with the former denoting 'Heavily influenced' and the latter 'Entirely independent'. The judiciary may be called upon to adjudicate cases relevant to a fossil fuel tax, and this control further helps isolate the public administration-specific measurement of governance risk. Next, different political cultures and beliefs about the role of the state in society can affect citizens' acceptance of government action. I controlled for the size of the government using an estimate of tax revenue as a percentage of gross domestic product (GDP) from the World Bank's Development Indicators (World Bank, 2016). Finally, I included a control for economic development using an estimate of GDP per capita (log transformed) in constant 2010 US dollars from the World Bank (2016). As Davidovic and Harring (2020) note, economic de- 
velopment is both relevant to environmental attitudes as well as endogenous to an extent with quality of government. As such, by including this measure in the model, I provided a particularly stringent test for the role of governance policy risk.

Finally, environmental degradation may affect the willingness to make personal sacrifices for the environment (Harring, 2013). I included an estimate of environmental health taken from the Environmental Performance Index published by the Yale Centre for Environmental Law and Policy (Hsu et al., 2018). The variable measures water and air quality, as well as the risk of these for human health. I included this factor as some have suggested that relative exposure to the effects of climate change and environmental degradation are related to both concern and support for policy action (Tranter and Booth, 2015).

\section{Results}

Table 1 shows the results of a series of multi-level ordered logistic regressions with support for fossil fuel taxation to address climate change as the dependent variable. Model 1 shows the relationship between climate change concern and support for fossil fuel taxation. Unsurprisingly, concern is positively linked with support. Model 2 adds basic demographic controls and Model 3 adds controls for values and beliefs. The positive, statistically significant relationship between climate change concern and the dependent variable persists in these models, as it does throughout all subsequent models.

Model 4 introduces governance risk into the model. As the country-level correlations suggest, governance risk is negatively related with the dependent variable: as governance risk increases, citizens are less likely to support fossil fuel taxation as a means to reduce climate change. Model 5 introduces economic risk. Again, the coefficient for this variable is negative and statistically significant, suggesting that economic risk undermines support for fossil fuel taxation.

To test hypotheses 3A and 3B, Models 6 and 7 introduce interaction terms between climate change concern and both governance and economic policy performance risk, respectively. I note that climate change concern was group-mean centered, and the country-level moderators were centered prior to inclusion in all models, though these transformations do not affect the results. The negative, statistically significant coefficients for the multiplicative terms are consistent with two hypotheses. In other words, as policy performance risk increases, the link between climate change concern and support for fossil fuel taxation grows weaker. The final model (Model 8) includes the country-level controls. While none of these controls is significant, the statistical significance of both species of policy performance risk, as well as the two interaction terms, persists.

Figure 3 graphs the predicted probabilities of a respondent choosing 'somewhat against' (value 2) vs 'somewhat for' (value 4) fossil fuel taxation based on the level of policy performance risk at the country level. The analyses underlying the graphs are similar to Model 8 above, with the difference being that climate concern is recoded as a binary variable capturing less concerned respondents (below or equal to the country mean of the scale) and more 
Table 1: Multi-level models of support for fossil fuel taxation

\begin{tabular}{|c|c|c|c|c|c|c|c|c|}
\hline & Model 1 & Model 2 & Model 3 & Model 4 & Model 5 & Model 6 & Model 7 & Model 8 \\
\hline \multirow[t]{2}{*}{ Climate change (CC) concern } & $0.45^{* * *}$ & $0.40 * * *$ & $0.34^{* * *}$ & $0.34^{* * *}$ & $0.34^{* * *}$ & $0.33^{* * *}$ & $0.32^{* * *}$ & $0.32^{* * *}$ \\
\hline & $(0.01)$ & $(0.01)$ & $(0.01)$ & $(0.01)$ & $(0.01)$ & $(0.04)$ & $(0.04)$ & $(0.04)$ \\
\hline \multirow[t]{2}{*}{ Age } & & $-0.01 * * *$ & $-0.00 * * *$ & $-0.00 * * *$ & $-0.00 * * *$ & $-0.00 * * *$ & $-0.00 * * *$ & $-0.00^{* * *}$ \\
\hline & & $(0.00)$ & $(0.00)$ & $(0.00)$ & $(0.00)$ & $(0.00)$ & $(0.00)$ & $(0.00)$ \\
\hline \multirow[t]{2}{*}{ Male respondent } & & $-0.07^{* * *}$ & $-0.08^{* * *}$ & $-0.08^{* * *}$ & $-0.08 * * *$ & $-0.09 * * *$ & $-0.09 * * *$ & $-0.09 * * *$ \\
\hline & & $(0.02)$ & $(0.02)$ & $(0.02)$ & $(0.02)$ & $(0.02)$ & $(0.02)$ & $(0.02)$ \\
\hline \multirow[t]{2}{*}{ Education } & & $0.09^{* * *}$ & $0.07^{* * *}$ & $0.07^{* * *}$ & $0.07^{* * *}$ & $0.06^{* * *}$ & $0.06^{* * *}$ & $0.06^{* * *}$ \\
\hline & & $(0.01)$ & $(0.01)$ & $(0.01)$ & $(0.01)$ & $(0.01)$ & $(0.01)$ & $(0.01)$ \\
\hline \multirow[t]{2}{*}{ Satisfaction with income } & & $0.21^{* * *}$ & $0.17^{* * *}$ & $0.17^{* * *}$ & $0.17^{* * *}$ & $0.17^{* * *}$ & $0.17^{* * *}$ & $0.17^{* * *}$ \\
\hline & & $(0.01)$ & $(0.01)$ & $(0.01)$ & $(0.01)$ & $(0.01)$ & $(0.01)$ & $(0.01)$ \\
\hline \multirow[t]{2}{*}{ Politically conservative } & & & $-0.07 * * *$ & $-0.07 * * *$ & $-0.07 * * *$ & $-0.07 * * *$ & $-0.07 * * *$ & $-0.07^{* * *}$ \\
\hline & & & $(0.00)$ & $(0.00)$ & $(0.00)$ & $(0.00)$ & $(0.00)$ & $(0.00)$ \\
\hline \multirow[t]{2}{*}{ Political trust } & & & $0.05^{* * *}$ & $0.05^{* * *}$ & $0.05^{* * *}$ & $0.05^{* * *}$ & $0.05^{* * *}$ & $0.05^{* * *}$ \\
\hline & & & $(0.00)$ & $(0.00)$ & $(0.00)$ & $(0.00)$ & $(0.00)$ & $(0.00)$ \\
\hline \multirow[t]{2}{*}{ General trust } & & & $0.03^{* * *}$ & $0.03^{* * *}$ & $0.03^{* * *}$ & $0.03^{* * *}$ & $0.03^{* * *}$ & $0.03^{* * *}$ \\
\hline & & & $(0.00)$ & $(0.00)$ & $(0.00)$ & $(0.00)$ & $(0.00)$ & $(0.00)$ \\
\hline \multirow[t]{2}{*}{ Humans cause climate change } & & & $0.20^{* * *}$ & $0.20^{* * *}$ & $0.20^{* * *}$ & $0.20^{* * *}$ & $0.20^{* * *}$ & $0.20^{* * *}$ \\
\hline & & & $(0.01)$ & $(0.01)$ & $(0.01)$ & $(0.01)$ & $(0.01)$ & $(0.01)$ \\
\hline \multirow{2}{*}{\multicolumn{2}{|c|}{ Other governments will take action }} & & $0.04^{* * *}$ & $0.04^{* * *}$ & $0.04^{* * *}$ & $0.04^{* * *}$ & $0.04^{* * *}$ & $0.04^{* * *}$ \\
\hline & & & $(0.00)$ & $(0.00)$ & $(0.00)$ & $(0.00)$ & $(0.00)$ & $(0.00)$ \\
\hline \multirow[t]{2}{*}{ Governance risk } & & & & $-1.55^{* * *}$ & $-1.18^{* *}$ & $-1.19 * *$ & $-1.19 * *$ & $-1.23^{*}$ \\
\hline & & & & $(0.45)$ & $(0.45)$ & $(0.46)$ & (0.46) & $(0.61)$ \\
\hline \multirow[t]{2}{*}{ Economic risk } & & & & & $-0.47^{*}$ & $-0.45^{*}$ & $-0.45^{*}$ & $-0.55^{*}$ \\
\hline & & & & & $(0.22)$ & $(0.23)$ & $(0.23)$ & $(0.22)$ \\
\hline \multirow[t]{2}{*}{ Governance risk $x$ CC concern } & & & & & & $-1.12^{* * *}$ & $-0.86 * *$ & $-0.86 * *$ \\
\hline & & & & & & $(0.30)$ & $(0.30)$ & $(0.30)$ \\
\hline \multirow[t]{2}{*}{ Economic risk $x \mathrm{CC}$ concern } & & & & & & & $-0.33^{*}$ & $-0.33^{*}$ \\
\hline & & & & & & & $(0.15)$ & $(0.15)$ \\
\hline \multirow[t]{2}{*}{ Democracy } & & & & & & & & -0.08 \\
\hline & & & & & & & & $(0.04)$ \\
\hline \multirow[t]{2}{*}{ Judicial independence } & & & & & & & & 0.00 \\
\hline & & & & & & & & $(0.07)$ \\
\hline \multirow[t]{2}{*}{ Tax revenue (\% of GDP) } & & & & & & & & 0.01 \\
\hline & & & & & & & & $(0.01)$ \\
\hline \multirow[t]{2}{*}{ GDP per capita } & & & & & & & & 0.09 \\
\hline & & & & & & & & $(0.14)$ \\
\hline Environmental Health & & & & & & & & -0.00 \\
\hline & & & & & & & & $(0.01)$ \\
\hline Cut 1 & -1.59 & -0.94 & 0.11 & 0.12 & 0.13 & 0.11 & 0.12 & 0.24 \\
\hline & $(0.10)$ & $(0.10)$ & $(0.11)$ & $(0.10)$ & $(0.10)$ & $(0.10)$ & $(0.10)$ & $(1.38)$ \\
\hline Cut 2 & -0.29 & 0.39 & 1.49 & 1.50 & 1.51 & 1.49 & 1.50 & 1.62 \\
\hline & $(0.10)$ & $(0.10)$ & $(0.11)$ & $(0.10)$ & $(0.10)$ & $(0.10)$ & $(0.10)$ & $(1.38)$ \\
\hline Cut 3 & 0.72 & 1.41 & 2.51 & 2.52 & 2.53 & 2.52 & 2.52 & 2.65 \\
\hline & $(0.10)$ & $(0.10)$ & $(0.11)$ & $(0.10)$ & $(0.10)$ & $(0.10)$ & $(0.10)$ & $(1.38)$ \\
\hline Cut 4 & 2.57 & 3.29 & 4.45 & 4.46 & 4.47 & 4.49 & 4.49 & 4.61 \\
\hline & $(0.10)$ & $(0.10)$ & $(0.11)$ & $(0.10)$ & $(0.10)$ & $(0.10)$ & $(0.10)$ & (1.38) \\
\hline Variance of constant & 0.21 & 0.17 & 0.11 & 0.07 & 0.06 & 0.06 & 0.06 & 0.04 \\
\hline & $(0.06)$ & $(0.05)$ & $(0.03)$ & $(0.02)$ & $(0.02)$ & $(0.02)$ & $(0.02)$ & $(0.01)$ \\
\hline Variance of CC concern & & & & & & 0.03 & 0.02 & 0.02 \\
\hline & & & & & & $(0.01)$ & $(0.01)$ & $(0.01)$ \\
\hline Countries & 23 & 23 & 23 & 23 & 23 & 23 & 23 & 23 \\
\hline Responses & 40,878 & 40,277 & 34,230 & 34,230 & 34,230 & 34,230 & 34,230 & 34230 \\
\hline
\end{tabular}

Note: ${ }^{*} p<0.05, * * p<0.01,{ }^{* * *} p<0.001$. Standard errors in parentheses. Dependent variable from the European Social Survey (Round 8, 2016): "To what extent are you in favour or against the following policies in [country] to reduce climate change? Item: Increasing taxes on fossil fuels, such as oil, gas and coal." Answers from 1 ("Strongly against") to 5 ("Strongly in favour").

Source: The author 
concerned respondents (above the mean). The graphs show that when risk (governance or economic) is low, preferences about fossil fuel taxation are determined more strongly by climate change concern (i.e., there is a larger difference between the two groups). However, the preferences of those with lower vs. higher levels of concern begin to converge as policy performance risk increases. This implies that the role of climate change concern in determining preferences about fossil fuel taxation matters less as the policy performance context becomes riskier.

\subsection{Subjective policy performance risk}

The principal analysis of this study is based on the theory that contextual factors that lower the probability of acceptable policy performance will weaken the link between climate change concern and support for fossil fuel taxation. However, although contextual variables should be conceived primarily as objective characteristics of the specific policy and implementation context, because they are linked to individual-level estimates of probable policy performance, we should expect that, first, subjective evaluations of policy performance risk will be correlated with objective measures and, second, that subjective evaluations of policy performance risk should likewise moderate the link between climate concern and support for policy action.

Based on these notions, I replicate the findings of Table 1 using subjective evaluations of policy performance risk. As argued above, governance risk is not policy-specific but rather affects general policy performance. In other words, governance risk is relevant not only to the performance of a fossil fuel taxation regime, but also other policies. I used a proxy of governance performance risk drawn from the ESS that asks respondents whether 'social benefits and services in [country] prevent widespread poverty?'. Of course, the design and implementation of public welfare services is different from that of a fossil fuel taxation regime, however, it is similarly complex and also intended to address a difficult policy challenge. If a government underperforms in implementing its social welfare program, it is reasonable to believe that it may also underperform in implementing a fossil fuel taxation regime. To capture economic policy risk, I used a second question asking the extent to which the individual is 'worried' that 'energy may be too expensive for many people in [country]'. Like the more objective measure of economic risk, this question is specific to the performance of a fossil fuel taxation regime and should likewise attenuate the link between climate change concern and support for fossil fuel taxation.

I estimated correlations between the contextual and subjective risk factors before performing the secondary analysis. Both the subjective estimations of governance and economic policy performance risk are positively correlated (at .40 and .41, respectively) with the contextual estimates at a $\mathrm{p}<.001$ statistical significance level. These statistics provide some evidence that the subjective measures are a reasonable proxy for the contextual measures.

Table 2 shows a series of additional regressions testing whether the key hypotheses of this study can be replicated using subjective measures of the moderating variables. Model 9 contains all individual and country level controls (not shown in the table), the two 

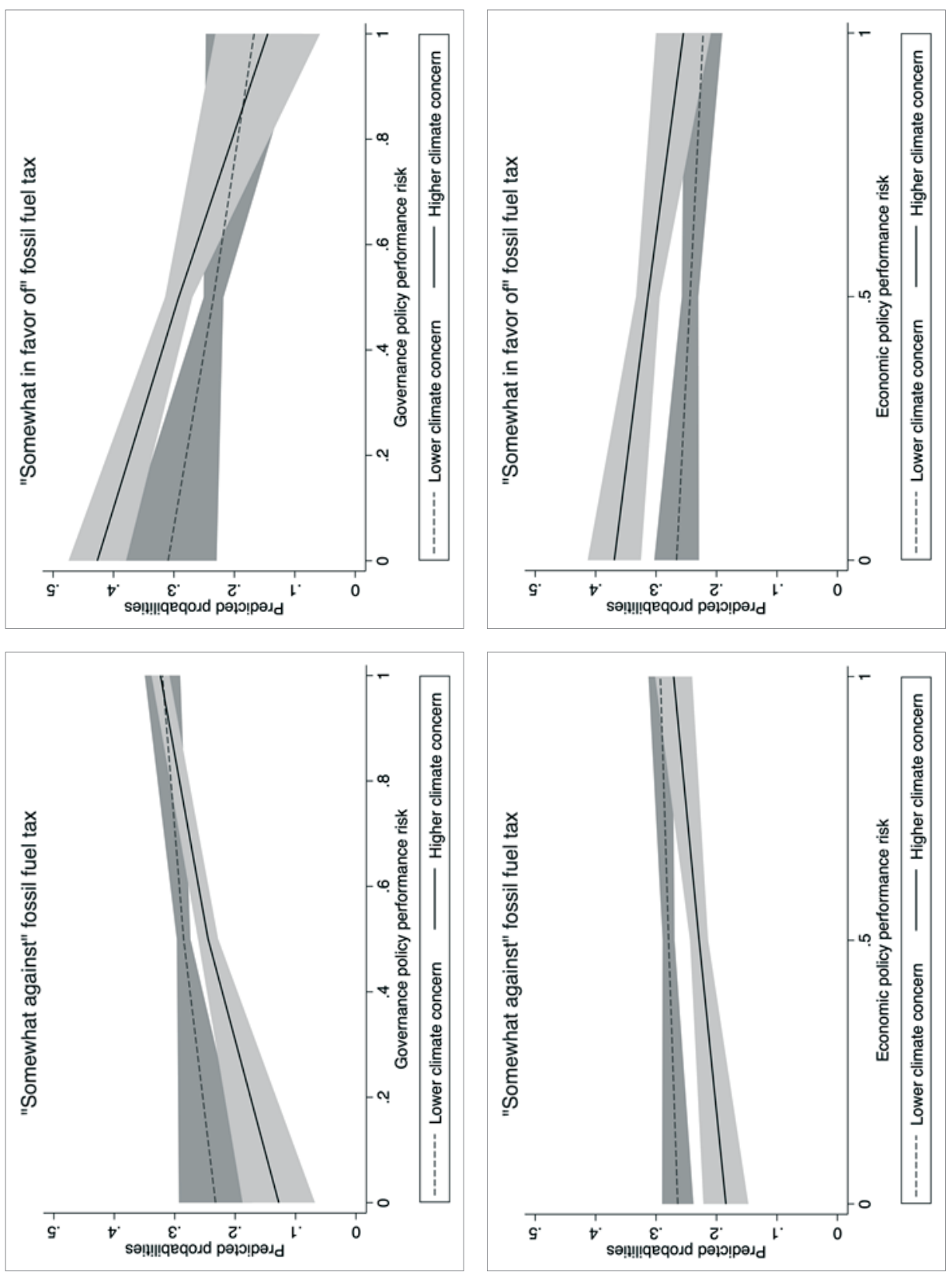

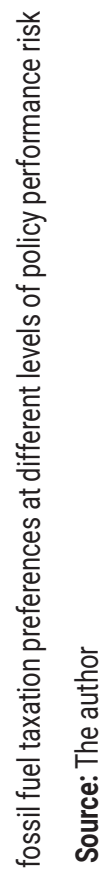

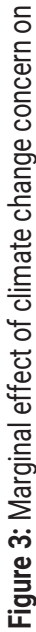


country-levels of policy performance risk (no longer significant), climate change concern, and the two subjective measures of policy performance risk. The results suggest that both subjective risk indicators are negatively correlated with support for fossil fuel taxation. Model 10 introduces an interaction term between subjective governance risk and climate change concern. As with the country-level variable, the subjective measure negatively moderates the relationship between concern and policy support. Model 11 introduces an additional interaction term between subjective economic risk and concern. The negative, statistically significant coefficient for this interaction likewise suggests that subjective economic policy performance risk negatively moderates the relationship between concern and policy support.

Table 2: Replication of main analysis using subjective estimates of policy performance risk

\begin{tabular}{|c|c|c|c|}
\hline & Model 9 & Model 10 & Model 11 \\
\hline \multirow[t]{2}{*}{ Climate change (CC) concern } & $0.384 * * *$ & $0.503 * * *$ & $0.731^{* * *}$ \\
\hline & $(0.014)$ & $(0.034)$ & $(0.048)$ \\
\hline \multirow[t]{2}{*}{ Governance risk } & -1.090 & -1.095 & -1.066 \\
\hline & $(0.576)$ & $(0.575)$ & $(0.571)$ \\
\hline \multirow[t]{2}{*}{ Economic risk } & $-0.436^{*}$ & $-0.434^{*}$ & $-0.426^{*}$ \\
\hline & $(0.211)$ & $(0.211)$ & $(0.209)$ \\
\hline \multirow[t]{2}{*}{ Governance risk (subjective) } & $-0.097 * * *$ & $-0.094 * * *$ & $-0.094 * * *$ \\
\hline & $(0.011)$ & $(0.011)$ & $(0.011)$ \\
\hline \multirow[t]{2}{*}{ Economic risk (subjective) } & $-0.216 * * *$ & $-0.215^{* * *}$ & $-0.216 * * *$ \\
\hline & $(0.011)$ & $(0.011)$ & $(0.011)$ \\
\hline \multirow[t]{2}{*}{ Governance risk (subjective) x CC concern } & & $-0.046 * * *$ & $-0.040 * *$ \\
\hline & & $(0.012)$ & $(0.012)$ \\
\hline \multirow[t]{2}{*}{ Economic risk (subjective) x CC concern } & & & $-0.079 * * *$ \\
\hline & & & $(0.011)$ \\
\hline \multirow[t]{2}{*}{ Cut 1} & -1.060 & -1.041 & -1.058 \\
\hline & $(1.312)$ & $(1.310)$ & $(1.300)$ \\
\hline \multirow[t]{2}{*}{ Cut 2} & 0.334 & 0.353 & 0.336 \\
\hline & $(1.312)$ & $(1.310)$ & $(1.300)$ \\
\hline \multirow[t]{2}{*}{ Cut 3} & 1.367 & 1.386 & 1.369 \\
\hline & $(1.312)$ & $(1.310)$ & $(1.300)$ \\
\hline \multirow[t]{2}{*}{ Cut 4} & 3.327 & 3.349 & 3.338 \\
\hline & $(1.312)$ & $(1.310)$ & $(1.301)$ \\
\hline \multirow[t]{2}{*}{ Variance of constant } & 0.040 & 0.040 & 0.039 \\
\hline & $(0.012)$ & $(0.012)$ & $(0.012)$ \\
\hline Countries & 23 & 23 & 23 \\
\hline Responses & 33,764 & 33,764 & 33,764 \\
\hline
\end{tabular}

Note: ${ }^{*} p<0.05, * * p<0.01, * * * p<0.001$. Standard errors in parentheses. Dependent variable from the European Social Survey (Round 8, 2016): "To what extent are you in favour or against the following policies in [country] to reduce climate change? Item: Increasing taxes on fossil fuels, such as oil, gas and coal." Answers from 1 ("Strongly against") to 5 ("Strongly in favour").

Source: The author 


\section{Discussion and conclusion}

Ambiguous information and evidence, conflicting interests, future discounting, the absence of a centralized authority, and a diminishing time horizon within which to act conspire to make addressing climate change a nearly intractable public policy challenge (Levin et al., 2012; Tompkins and Adger, 2005). Because a climate policy of sufficient scope and ambition will entail sacrifices for everyone in society, it is necessary for the population to broadly support its adoption and implementation. This study looked at the relationship between concern about climate change and support for increased taxes on fossil fuels using a large sample of European survey respondents. Unsurprisingly, concern is associated with support for fossil fuel taxation. However, due to the complex and potentially costly nature of fossil fuel taxation policy, I theorized that factors that increase the probability of poor policy performance would temper the relationship between concern and policy support. I conceptualized these risks in terms of public administration-specific factors and economic factors uniquely relevant to the introduction of a fossil fuel tax. The results suggest that the positive relationship between concern and policy support weakens as policy performance risk rises, and that concern ultimately becomes a poor predictor of policy preferences in high-risk contexts.

Although the results of the study are compelling and consistent with the theoretical position, its limitations are non-trivial and should be addressed in future work. First, European countries are not representative of the general case, being both highly developed and, by the same token, relatively larger consumers of fossil fuels. Although the countries in the sample do represent a range of policy performance risk situations, in global terms, they are undoubtedly at the lower end of the scale. Future work should use a more diverse sample of countries to test the generalizability of the effect. The second limitation of the study also relates to the data. Although the ESS has been conducted for many rounds and panel data can be constructed for a number of individual-level variables, the climate change module relevant to this study was used only once. Not only would panel data allow us to explore the effect of, for instance, how policy performance risk shapes perceptions of climate change policy over time, but it would also allow us to better understand how environmental variables potentially play a greater role as climate change accelerates.

Despite these limitations, the study has both practical and theoretical implications. First, the results suggest that policy performance risk, whether measured in terms of governance risk or economic risk, negatively impacts support for fossil fuel taxation. This finding is not surprising; however, it is somewhat discouraging given the inherent difficulties involved in reducing policy performance risk. The factors driving governance risk are myr$\operatorname{iad}$ (Peters, 2015), and, given the negative correlation between GDP per capita and governance risk, economic development may itself be a condition for lowering policy risk. Measured as fossil fuel production/consumption rates, economic risk is also correlated with GDP per capita, however, the correlation is smaller. This suggests that while economic risk may be negatively related to support for climate policy action, factors beyond economic risk also drive support. Although not hypothesized in this study, a question left to future 
research is whether governance policy performance risk rises in importance as a driver of fossil fuel taxation policy support for those with high levels of concern as economic policy performance risk increases. This case would represent a compounding effect of the two risk types. In the opposite scenario, governance risk may become less impactful as a driver of policy preferences among highly concerned citizens in the presence of higher economic risk. Modeling and estimating the effect size of this potential three-way interaction is beyond the scope of the present study. However, understanding the relationship between the different types of policy performance risk may provide further insight into the mechanisms driving support for fossil fuel and other climate change mitigation policies.

Second, the moderating effect of policy performance risk on the relationship between climate change concern and support for fossil fuel taxation is discouraging from a practical perspective. It is not a surprise that those who have a stronger concern about the effects of climate change would support more ambitious policy action. However, I argued that the relationship between concern and policy support would be tempered by policy performance risk. And yet, the opposite hypothesis is not inconceivable: those who have a strong commitment to a particular policy agenda may be willing to support ambitious policy action even in the face of substantial risk. Stated differently, high levels of (climate change) concern could positively moderate the relationship between policy performance risk and (fossil fuel taxation) policy support. The results of the empirical analysis do not support this alternative hypothesis. Rather, even those most concerned may come to resemble those with lower levels of concern when risk is high. From an empirical perspective, future research may specify the moderated relationship between concern and risk as nonlinear and thereby attempt to identify a level of concern beyond which policy risk itself becomes a non-deterrent to policy support.

Left unchecked, climate change is an existential threat. Currently, securing sufficient democratic support for policy to address climate change is a necessary condition for its adoption. Clearly presenting evidence for the causes of climate change and communicating its likely consequences in an unbiased and politically neutral manner can help raise levels of concern and win over climate change skeptics. However, even sufficiently concerned citizens will have legitimate reservations about ambitious climate change policy in the face of significant policy performance risk. In this study I provide evidence that contextual factors underlying policy performance risk can weaken the link between climate change concern and support for fossil fuel taxation. Addressing systemic governance and economic risk is difficult and beset with collective action problems and a lack of incentives for elites who benefit from the status quo. The results of this study, however, suggest that the stakes attached to lowering policy performance risk and adopting effective climate change policy coincide. The longer addressing these risks is delayed, the more likely it becomes that our hand is forced, and costly environmental policy is adopted with or without public support. 


\section{References:}

1. Ahn, Y. and Campbell, J.W., 'Red Tape, Rule Legitimacy, and Public Service Motivation: Experimental Evidence from Korean Citizens', 2022, Administration \& Society, online first, pp. 1-38, DOI: https://doi.org/10.1177/00953997211069046.

2. Aldy, J.E. and Stavins, R.N., 'The Promise and Problems of Pricing Carbon: Theory and Experience', 2012, Journal of Environment \& Development, vol. 21, no. 2, pp. 152-180.

3. Baldwin, D.A., 'Success and Failure in Foreign Policy', 2000, Annual Review of Political Science, vol. 3, no. 1, pp. 167-182.

4. Bamberg, S. and Möser, G., 'Twenty Years After Hines, Hungerford, and Tomera: A New Meta-Analysis of Psycho-Social Determinants of Pro-Environmental Behaviour', 2007, Journal of Environmental Psychology, vol. 27, no. 1, pp. 14-25.

5. Bovens, M. and 't Hart, P., 'Revisiting the Study of Policy Failures', Journal of European Public Policy, vol. 23, no. 5, pp. 653-666.

6. Bozeman, B., 'A Theory of Government 'Red Tape', 1993, Journal of Public Administration Research and Theory, vol. 3, no. 3, pp. 273-304.

7. Campbell, J.W., 'Obtrusive, Obstinate and Conspicuous: Red Tape from a Heideggerian Perspective', 2019, International Journal of Organizational Analysis, vol. 27, no. 5, pp. 1657-1672.

8. Campbell, J.W., 'Red Tape, Rule Burden, and Legitimate Performance Trade-Offs: Results from a Vignette Experiment', 2020a, Public Performance \& Management Review, vol. 43, no. 4, pp. 741-765.

9. Campbell, J.W., 'Buying the Honor of Thieves? Performance Pay, Political Patronage, and Corruption', 2020b, International Journal of Law, Crime and Justice, vol. 63, art. 100439, DOI: https://doi.org/10.1016/j.ijlcj.2020.100439.

10. Campbell, J.W., 'Evolution and Change in Public Organizations: Efficiency, Legitimacy and the Resilience of Core Organizational Elements', in Bryer, T.A. (ed.), Handbook of Theories of Public Administration and Management, Cheltenham, UK: Edward Elgar Publishing, 2021, pp. 221-233.

11. Chan, H.W., Pong, V. and Tam, K.P., 'Cross-National Variation of Gender Differences in Environmental Concern: Testing the Sociocultural Hindrance Hypothesis', 2019, Environment and Behavior, vol. 51, no. 1, pp. 81-108.

12. Chowdhury, S.K., 'The Effect of Democracy and Press Freedom on Corruption: An Empirical Test, 2004, Economics Letters, vol. 85, no. 1, pp. 93-101.

13. Cruz, S.M., 'The Relationships of Political Ideology and Party Affiliation with Environmental Concern: A Meta-Analysis', 2017, Journal of Environmental Psychology, vol. 53, pp. 81-91.

14. Dahlström, C., Lapuente, V. and Teorell, J., 'The Merit of Meritocratization: Politics, Bureaucracy, and the Institutional Deterrents of Corruption', 2012, Political Research Quarterly, vol. 65, no. 3, pp. 656-668.

15. Dahlström, C., Teorell, J., Dahlberg, S., Hartmann, F., Lindberg, A. and Nistotskaya, M., 'The QoG Expert Survey II Report', The QoG Working Paper Series 2015:9, Gothenburg, 2015a, [Online] available at https://gupea.ub.gu.se/handle/2077/39869, accessed on January 15, 2022.

16. Dahlström, C., Teorell, J., Dahlberg, S., Hartmann, F., Lindberg, A. and Nistotskaya, M., 'The QoG Expert Survey Dataset II', University of Gothenburg, The Quality of Government Insti- 
tute, 2015b, [Online] available at https://qog.pol.gu.se/data/datadownloads/qogexpertsurveydata, accessed on January 15, 2022.

17. Davidovic, D. and Harring, N., 'Exploring the Cross-National Variation in Public Support for Climate Policies in Europe: The Role of Quality of Government and Trust, 2020, Energy Research \& Social Science, vol. 70, 101785, DOI: https://doi.org/10.1016/j.erss.2020.101785.

18. Davidovic, D., Harring, N. and Jagers, S.C., 'The Contingent Effects of Environmental Concern and Ideology: Institutional Context and People's Willingness to Pay Environmental Taxes', 2020, Environmental Politics, vol. 29, no. 4, pp. 674-696.

19. de Jong, G. and van Witteloostuijn, A., 'Regulatory Red Tape and Private Firm Performance', 2015, Public Administration, vol. 93, no. 1, pp. 34-51.

20. Doyle, J., 'Institutionalized Collective Action and the Relationship between Beliefs about Environmental Problems and Environmental Actions: A Cross-national Analysis', 2018, Social Science Research, vol. 75, pp. 32-43.

21. Dreyer, S.J. and Walker, I., 'Acceptance and Support of the Australian Carbon Policy', 2013, Social Justice Research, vol. 26, no. 3, pp. 343-362.

22. Dunlap, R.E. and Jones, R.E., 'Environmental Concern: Conceptual and Measurement Issues', in Dunlap, R.E. and Michelson, W. (eds.), Handbook of Environmental Sociology, Westport CN: Greenwood Press, 2002, pp. 482-524.

23. Easton, D., 'A Re-Assessment of the Concept of Political Support', 1975, British Journal of Political Science, vol. 5, no. 4, pp. 435-457.

24. Echavarren, J.M., 'From Objective Environmental Problems to Subjective Environmental Concern: A Multilevel Analysis Using 30 Indicators of Environmental Quality', 2017, Society \& Natural Resources, vol. 30, no. 2, pp. 145-159.

25. Eriksson, L., Garvill, J. and Nordlund, A.M., 'Acceptability of Single and Combined Transport Policy Measures: The Importance of Environmental and Policy Specific Beliefs', 2008, Transportation Research Part A: Policy and Practice, vol. 42, no. 8, pp. 1117-1128.

26. European Social Survey, 'ESS8: European Social Survey Round 8 Data', 2016, Data file edition 2.2, Norwegian Centre for Research Data, Norway (Data archive and distributor of ESS data for ESS ERIC), DOI:10.21338/NSD-ESS8-2016.

27. Evans, P. and Rauch, J.E., 'Bureaucracy and Growth: A Cross-National Analysis of the Effects of 'Weberian' State Structures on Economic Growth', 1999, American Sociological Review, vol. 64, no. 5, pp. 748-765.

28. Fairbrother, M., 'Trust and Public Support for Environmental Protection in Diverse National Contexts', 2016, Sociological Science, vol. 3, pp. 359-382.

29. Fairbrother, M., Arrhenius, G., Bykvist, K. and Campbell, T., 'Governing for Future Generations: How Political Trust Shapes Attitudes Towards Climate and Debt Policies', 2021, Frontiers in Political Science, vol. 3, art. 656053, DOI: https://doi.org/10.3389/fpos.2021.656053.

30. Fairbrother, M., Sevä, J.I. and Kulin, J., 'Political Trust and The Relationship Between Climate Change Beliefs and Support for Fossil Fuel Taxes: Evidence from a Survey of 23 European Countries', 2019, Global Environmental Change: Human and Policy Dimensions, vol. 59, art. 102003, DOI: https://doi.org/10.1016/j.gloenvcha.2019.102003.

31. Freedom House, 'Freedom in the World 2018', 2019, [Online] available at https://freedom house.org/report/freedom-world, accessed on January 15, 2022. 
32. George, B., Pandey, S.K., Steijn, B., Decramer, A. and Audenaert, M., 'Red Tape, Organizational Performance and Employee Outcomes: Meta-Analysis, Meta-Regression and Research Agenda', 2021, Public Administration Review, vol. 81, no. 4, pp. 638-651.

33. Hao, F., 'A Panel Regression Study on Multiple Predictors of Environmental Concern for 82 Countries Across Seven Years: A Cross-National Study of Environmental Concern', 2016, Social Science Quarterly, vol. 97, no. 5, pp. 991-1004.

34. Hao, F., Liu, X. and Michaels, J.L., 'Social Capital, Carbon Dependency, and Public Response to Climate Change in 22 European Countries', 2020, Environmental Science \& Policy, vol. 114, pp. 64-72.

35. Harring, N., 'Understanding the Effects of Corruption and Political Trust on Willingness to Make Economic Sacrifices for Environmental Protection in a Cross-National Perspective: Economic Sacrifices for Environmental Protection', 2013, Social Science Quarterly, vol. 94, no. 3, pp. 660-671.

36. Harring, N., Jagers, S.C. and Matti, S., 'The Significance of Political Culture, Economic Context and Instrument Type for Climate Policy Support: A Cross-National Study', 2019, Climate Policy, vol. 19, no. 5, pp. 636-650.

37. Hornsey, M.J., Harris, E.A., Bain, P.G. and Fielding, K.S., 'Meta-Analyses of the Determinants and Outcomes of Belief in Climate Change', 2016, Nature Climate Change, vol. 6, no. 6, pp. 622-626.

38. Howlett, M., 'The Lessons of Failure: Learning and Blame Avoidance in Public Policy-Making', 2012, International Political Science Review, vol. 33, no. 5, pp. 539-555.

39. Hox, J.J., Moerbeek, M. and van de Schoot, R., Multilevel Analysis: Techniques and Applications, $3^{\text {rd }}$ edition, New York: Routledge, 2017.

40. Hsu, A., Etsy, D.C., Levy, M. and de Sherbinin, A., '2016 Environmental Performance Index', Yale Center for Environmental Law and Policy, 2018, [Online] available at www.epi.yale.edu, accessed on January 15, 2022.

41. Kalenborn, C. and Lessmann, C., 'The Impact of Democracy and Press Freedom on Corruption: Conditionality Matters', 2013, Journal of Policy Modeling, vol. 35, no. 6, pp. 857-886.

42. Kaufmann, W., Hooghiemstra, R. and Feeney, M.K., 'Formal Institutions, Informal Institutions, and Red Tape: A Comparative Study', 2018, Public Administration, vol. 96, no. 2, pp. 386-403.

43. Kollmuss, A. and Agyeman, J., 'Mind the Gap: Why Do People Act Environmentally and What Are the Barriers to Pro-Environmental Behavior?', 2002, Environmental Education Research, vol. 8, no. 3, pp. 239-260.

44. Kulin, J. and Johansson Sevä, I., 'Who Do You Trust? How Trust in Partial and Impartial Government Institutions Influences Climate Policy Attitudes', 2021, Climate Policy, vol. 21, no. 1, pp. 33-46.

45. Levin, K., Cashore, B., Bernstein, S. and Auld, G., 'Overcoming the Tragedy of Super Wicked Problems: Constraining our Future Selves to Ameliorate Global Climate Change’, 2012, Policy Sciences, vol. 45, no. 2, pp. 123-152.

46. Luís, S., Vauclair, C.M. and Lima, M.L., 'Raising Awareness of Climate Change Causes? Cross-National Evidence for the Normalization of Societal Risk Perception of Climate Change', 2018, Environmental Science \& Policy, vol. 80, pp. 74-81. 
47. Mayerl, J. and Best, H., 'Two Worlds of Environmentalism? Empirical Analyses on the Complex Relationship between Postmaterialism, National Wealth, and Environmental Concern', 2018, Nature and Culture, vol. 13, no. 2, pp. 208-231.

48. McConnell, A., 'Policy Success, Policy Failure and Grey Areas In-Between', 2010, Journal of Public Policy, vol. 30, no. 3, pp. 345-362.

49. McConnell, A., 'A Public Policy Approach to Understanding the Nature and Causes of Foreign Policy Failure', 2016, Journal of European Public Policy, vol. 23, no. 5, pp. 667-684.

50. Mungiu-Pippidi, A., Dadasov, R., Martínez, R., Kukutschka, B., Alvarado, N., Dykes, V., Kossow, N. and Khaghaghordyan, A., 'Index of Public Integrity', European Research Centre for Anti-Corruption and State-Building (ERCAS), 2017, [Online] available at https://www.again stcorruption.eu/homepage-widgets/index-of-public-integrity/, accessed on January 15, 2022.

51. Nawrotzki, R.J., 'The Politics of Environmental Concern: A Cross-National Analysis', 2012, Organization \& Environment, vol. 25, no. 3, pp. 286-307.

52. Newman, J. and Head, B.W., 'Categories of Failure in Climate Change Mitigation Policy in Australia', 2015, Public Policy and Administration, vol. 30, no. 3-4, pp. 342-358.

53. Olavarría-Gambi, M., 'Policy Failure Revisited: Conceptual Implications from the Chilean Case of Transantiago', 2020, Administration \& Society, vol. 52, no. 5, pp. 690-717.

54. Pampel, F.C., 'The Varied Influence of SES on Environmental Concern', 2014, Social Science Quarterly, vol. 95, no. 1, pp. 57-75.

55. Pandey, S.K., 'The Psychological Process View of Bureaucratic Red Tape', in Steijn, B. and Knies, E. (eds.), Research Handbook on HRM in the Public Sector, Cheltenham, UK: Edward Elgar Publishing, 2021, pp. 260-275.

56. Peters, B.G., 'State Failure, Governance Failure and Policy Failure: Exploring the Linkages', 2015, Public Policy and Administration, vol. 30, no. 3-4, pp. 261-276.

57. Pohjolainen, P., Kukkonen, I., Jokinen, P., Poortinga, W., Adedayo Ogunbode, C., Böhm, G., Fisher, S. and Umit, R., 'The Role of National Affluence, Carbon Emissions, and Democracy in Europeans' Climate Perceptions', 2021, Innovation: The European Journal of Social Science Research, pp. 1-19, DOI: https://doi.org/10.1080/13511610.2021.1909465.

58. Poortinga, W., Whitmarsh, L., Steg, L., Bohm, G. and Fisher, S., 'Climate Change Perceptions and their Individual-Level Determinants: A Cross-European Analysis', 2019, Global Environmental Change-Human and Policy Dimensions, vol. 55, pp. 25-35.

59. Rafaty, R., 'Perceptions of Corruption, Political Distrust, and the Weakening of Climate Policy', 2018, Global Environmental Politics, vol. 18, no. 3, pp. 106-129.

60. Schade, J. and Schlag, B., 'Acceptability of Urban Transport Pricing Strategies', 2003, Transportation Research Part F: Traffic Psychology and Behaviour, vol. 6, no. 1, pp. 45-61.

61. Schultz, W.P., 'The Structure of Environmental Concern: Concern for Self, Other People, and the Biosphere', 2001, Journal of Environmental Psychology, vol. 21, no. 4, pp. 327-339.

62. Smith, E.K. and Mayer, A., 'A Social Trap for the Climate? Collective Action, Trust and Climate Change Risk Perception in 35 Countries', 2018, Global Environmental Change: Human and Policy Dimensions, vol. 49, pp. 140-153.

63. Sundblad, E.L., Biel, A. and Gärling, T., 'Cognitive and Affective Risk Judgements Related to Climate Change’, 2007, Journal of Environmental Psychology, vol. 27, no. 2, pp. 97-106.

64. Sundell, A., 'Are Formal Civil Service Examinations the Most Meritocratic Way to Recruit Civil Servants? Not in All Countries', 2014, Public Administration, vol. 92, no. 2, pp. 440-457. 
65. Svallfors, S., 'Government Quality, Egalitarianism, and Attitudes to Taxes and Social Spending: A European Comparison', 2013, European Political Science Review, vol. 5, no. 3, pp. 363-380.

66. Tam, K.P. and Chan, H.W., 'Environmental Concern has a Weaker Association with Pro-Environmental Behavior in Some Societies than Others: A Cross-Cultural Psychology Perspective', 2017, Journal of Environmental Psychology, vol. 53, pp. 213-223.

67. Tam, K.P. and Chan, H.W., 'Generalized Trust Narrows the Gap Between Environmental Concern and Pro-Environmental Behavior: Multilevel Evidence', 2018, Global Environmental Change: Human and Policy Dimensions, vol. 48, pp. 182-194.

68. Teorell, J., Dahlberg, S., Holmberg, S., Rothstein, B., Pachon, N. and Svensson, R., 'The Quality of Government Standard Dataset, Version Jan18', University of Gothenburg, The Quality of Government Institute, 2018, [Online] available at http://www.qog.pol.gu.se, accessed on January 15, 2022.

69. The World Bank, 'World Development Indicators', Washington DC, 2016.

70. Themudo, N.S., 'Reassessing the Impact of Civil Society: Nonprofit Sector, Press Freedom, and Corruption', 2013, Governance - An International Journal of Policy Administration and Institutions, vol. 26, no. 1, pp. 63-89.

71. Tompkins, E.L. and Adger, N.W., 'Defining Response Capacity to Enhance Climate Change Policy', 2005, Environmental Science \& Policy, vol. 8, no. 6, pp. 562-571.

72. Tranter, B. and Booth, K., 2015, 'Scepticism in a Changing Climate: A Cross-National Study', Global Environmental Change, vol. 33, pp. 154-164.

73. Umit, R. and Schaffer, L.M., 'Attitudes Towards Carbon Taxes Across Europe: The Role of Perceived Uncertainty and Self-Interest', 2020, Energy Policy, vol. 140, art. 111385, DOI: https://doi.org/10.1016/j.enpol.2020.111385.

74. Van Heuvelen, T. and Summers, N., 'Divergent Roads: A Cross-National Intercohort Analysis of Affluence and Environmental Concern', 2019, Social Science Research, vol. 82, pp. 72-91.

75. World Economic Forum, 'The Global Competitiveness Report 2017-2018', 2017, [Online] available at http://reports.weforum.org/global-competitiveness-index-2017-2018/downloads/, accessed on January 15, 2022. 